\title{
Źródła z epoki jako świadectwa polskiej i rosyjskiej recepcji opery Wincentego Ignacego Marewicza Polusia, córka kotodzieja, czyli Wolność oswobodzona...'
}

\author{
Anna Petlak \\ (Uniwersytet Łódzki)
}

Wincenty Ignacy Marewicz (I755-I822) urodził się na Litwie, uczył się w szkołach jezuickich w Wilnie. Po 1776 roku rozpoczął kilkuletnią podróż po kraju, przebywał między innymi w Płocku, Grodnie, Wilnie, Krakowie. Zadebiutował w I784 roku, publikując anonimowo w periodyku literackim „Magazyn Warszawski” fragment wiersza Kalendarz powszechny na wszystkie lata, natomiast apogeum jego aktywności twórczej i wydawniczej przypada na lata I786-1789. Był gorliwym rzecznikiem reform ustrojowych i społecznych, co znalazło odzwierciedlenie w jego twórczości publicystycznej towarzyszącej obradom Sejmu Czteroletniego (na przykład tekst Do stanów sejmujacych, wiersz, w którym odwołał się do napisanego dwa lata wcześniej projektu politycznego $O$ dobrowolnych podatkach. Projekt na sejm). W I79I roku książę Maciej Radziwiłł kupił dla Marewicza domek i niewielki obszar ziemi na Eukiszkach, pisarz został też wybrany na urzędnika municypalnego w Wilnie. Podczas wojny polsko-rosyjskiej I792 roku przeznaczył nagrodę (akt własności kamienicy) dla ochotnika, który najbardziej zasłuży się w walce, a na potrzeby wojska ofiarował między innymi swój domek z ogrodem i ponad 200 zł w gotówce. W czasie powstania kościuszkowskiego pisarz i jego żona (osoba bliżej nieznana) dołączyli do wojska jako zwykli żołnierze. Pod koniec 1798 roku Marewicz przebywał we Lwowie. Po I8oo roku zamieszkał w Warszawie, gdzie był urzędnikiem stanu cywilnego i członkiem loży wolnomularskiej Świątynia Izis. W tym mieście zmarł 5 marca I822 roku$^{2}$.

1 Publikacja prezentuje wyniki badań finansowanych przez Narodowe Centrum Nauki na podstawie decyzji nr DEC-2011/01/D/HS2/02852.

2 Zob. E. Aleksandrowska, Wincenty Ignacy Marewicz (1755-1822), w: Pisarze polskiego oświecenia, red. T. Kostkiewiczowa, Z. Goliński, t. 2, Warszawa 1994, s. 332-341. 
Pisarski dorobek Marewicza jest bogaty i zróżnicowany pod względem gatunkowym oraz tematycznym. Przeważają teksty związane z osobą starościanki pińskiej Barbary Jelskiej lub jej poświęcone (poznana przez twórcę w 1776 roku Jelska, nazywana w utworach Laurą, była jego wieloletnią nieodwzajemnioną miłością). Za życia autora w druku ukazało się między innymi sześć utworów dramatycznych (komedie, dramy, opera), trzy tomiki poetyckie (zawierające wiersze okolicznościowe, osobiste, erotyki, pieśni, bajki, epigramaty, sielanki itd.), cztery zbiory pism wierszem i prozą bądź prozą z wierszem (w tym listy menipejskie, traktaty, przemowy, scenki obyczajowe) $)^{3}$.

Jednym z najbardziej znanych utworów Marewicza jest Polusia, córka kotodzieja, czyli Wolność oswobodzona. Opera tragiczna w dwóch aktach, w wydaniach z epoki opatrzona adnotacją: „z rosyjskiego na polski język przetłumaczona”. Ze względu na polityczny charakter i antyrosyjską wymowę dzieło przez pewien czas mylnie przypisywano Julianowi Ursynowi Niemcewiczowi, co odnotował Karol Estreicher w swojej bibliografii: „Cała sztuka wymierzona przeciw ówczesnym stosunkom politycznym. Może dlatego w katalogu Biblioteki Jagiellońskiej zaznaczono, że to pióra Niemcewicza"4. Informację tę potwierdza odręczna notatka sporządzona (zapewne przez bibliotekarza) 29 grudnia I894 roku na karcie przedtytułowej egzemplarza Polusi... z I79I roku, znajdującego się obecnie w zbiorach Biblioteki Jagiellońskiej: „Zdaje się, że uchodził za utwór Niemcewicza z powodu tendencji politycznej, bo na karcie Bibliot[eki] Jagiellońskiej zanotowano [tu: nieczytelnie zapisane nazwisko - A. P.], że autor - Julian Niemcewicz"s.

Warto dodać, że mylna atrybucja dzieła może również świadczyć o walorach artystycznych sztuki Marewicza, ale najprawdopodobniej (poza zastosowaniem

3 Marewicz jest też autorem obszernych utworów o charakterze osobistym, które ukazały się jako osobne druki (np. Doświadczenie czyli myśl w chorobie, Gotąbek, Wariacja. Wiersz nowego rodzaju, Ostatnia do Laury odezwa. Wierszem i proza, Uwaga nad losem biednej Tekluni z prośbą do króla), wierszy patriotycznych, politycznych i panegirycznych, opublikowanych w postaci druków ulotnych, oraz zbioru Przystowia i maksymy. Pośmiertnie wydano jego poemat z 1794 r. pt. Nefelonikones, urywki z ociemiecielstwa. Zbiór osobliwych obrazów z dziet dawnego świata (Paryż 1836).

Przez swoich współczesnych pisarz uznawany był najczęściej za grafomana i dziwaka. Dopiero od drugiej połowy XX w. kształtuje się inny pogląd na osobę i pisarstwo Marewicza, m.in. w opiniach Jerzego Jackla (Litteraria, w: Teatr Narodowy 1765-1794, red. J. Kott, oprac. J. Jackl, B. Król-Kaczorowska, J. Pawłowiczowa, K. Wierzbicka-Michalska, Z. Wołoszyńska, W. Zawadzki, Warszawa 1967, s. 426), Elżbiety Aleksandrowskiej (op. cit., s. 332), Juliusza Wiktora Gomulickiego (Coś nowego o „Sprzeczkach” Jakuba Jasińskiego, w: W'śód pisarzy oświecenia. Studia i portrety, red. A. Czyż i S. Szczęsny, Bydgoszcz 1997, s. 118), Aleksandra Lipatowa (Początki polskiej prozy preromantycznej XVIII wieku. Ewolucja myśli artystycznej oraz przemiany gatunkowe na tle narodowego i europejskiego procesu literackiego, tłum. J. Aulak, M. Dobrogoszcz, w: idem, Stowiańszczyzna - Polska - Rosja. Studia o literaturze i kulturze, Izabelin 1999, s. 147-178).

4 K. Estreicher, Bibliografia polska, cz. 3, t. 11 (22): M-My, Kraków 1908, s. 151.

5 Zob. [W.I. Marewicz], Polusia, córka kotodzieja, czyli Wolność oswobodzona. Opera tragiczna w dwóch aktach, z rosyjskiego na polski język przetłumaczona, [b.m.] 1791, k. przedtytułowa recto, Biblioteka Jagiellońska w Krakowie (dalej jako BJ), sygn. 26665 I. 
wyrazistej alegorii i widocznym temperamentem satyrycznym) zadecydowała o tym przypuszczeniu wymowa polityczna utworu, zbieżna z poglądami, które Niemcewicz głosił w czasie Sejmu Czteroletniego.

Opera ukazywała się drukiem w I789 i I79I roku, w obu przypadkach bez wskazania autora i miejsca wydania. Zamieszczona natomiast w Spisie darów, uczynionych dla Zaktadu Narodowego imienia Ossolinskich... informacja o edycji Polusi... z I780 roku ${ }^{6}$ to najprawdopodobniej pomyłka. Karol Estreicher odnotował dwa wydania z I789 roku $\mathrm{w}$ formacie $8^{\circ}$ - pierwsze liczące Iog stron, natomiast drugie 93 strony, a także jedno z I79I roku w formacie $4^{\mathrm{o}}$, które obejmowało Io3 strony ${ }^{7}-\mathrm{w}$ żadnym $\mathrm{z}$ nich nie podano miejsca druku. W Bibliografii literatury polskiej „Nowy Korbut” powtórzono te informacje. Przy wydaniu z I79r roku wskazano Lwów jako przypuszczalne miejsce druku $^{8}$, co odnotowała później Elżbieta Aleksandrowska w biogramie Marewicza9. Nie wiadomo jednak, na jakiej podstawie powstało to przypuszczenie. Kwestia ta wymaga zatem dodatkowych, bardziej wnikliwych badań.

W 20I7 roku dotychczasowe informacje o edycjach opery Marewicza wzbogaciła Iryna Ciborowska-Rymarowicz (pracownik Oddziału Starych Druków i Rzadkich Ksiąg Biblioteki Narodowej Ukrainy im. W.I. Wernadskiego w Kijowie), której zainteresowania naukowe koncentrują się między innymi na działalności drukarni karmelitów bosych w Berdyczowie. Przeprowadzone studia historyczno-bibliograficzne i analiza typograficzna pozwoliły badaczce jedną edycję z I789 roku (egzemplarz w zbiorach kijowskiej Biblioteki Narodowej Ukrainy oznaczony sygnaturą Bos. комітет I40o) rozpoznać właśnie jako druk oficyny berdyczowskiej. Na podstawie analizy porównawczej tomu oraz wydanych w tym samym roku trzech innych egzemplarzy Polusi..., przechowywanych we wskazanej już bibliotece kijowskiej (sygn. In. 6330), a także we Lwowskiej Narodowej Naukowej Bibliotece Ukrainy im. W. Stefanyka (sygn. Ст-I 78247) i Bibliotece Zakładu Narodowego im. Ossolińskich we Wrocławie (sygn. XVIII-II.994), Ciborowska-Rymarowicz wykazała różnice między nimi i wysunęła przypuszczenie, że w I789 roku opera Marewicza została wydana co najmniej czterokrotnie. Ustalenia te przedstawiła w referacie wygłoszonym na międzynarodowej konferencji naukowej Biblioteka. Nauka. Komunikacja. Strategiczne

6 Zob. Spis darów, uczynionych dla Zaktadu Narodowego imienia Ossolińskich oraz i dawców tychże, w ciagu roku 1833, „Czasopismo Naukowe od Zakładu Narodowego imienia Ossolińskich wydawane” 1833, z. 8, s. 87 (http://www.wbc.poznan.pl/dlibra/doccontent?id=114149, stan z 2 marca 2019 r.).

7 K. Estreicher, Bibliografia polska, cz. 3, t. 11..., s. 151. Zob. także idem, Bibliografia polska, cz. 2: Stulecie XV-XIX. Spis chronologiczny, t. 2 (9): Stulecie XVIII i dopetnienia do wieku XV-XVII, Kraków 1888, s. 581, 583, 628; idem, Bibliografia polska XIX stulecia, t. 4: D-Dramat polski, wyd. 2, red. K. Estreicher (junior), Kraków 1966, s. 332.

8 Zob. Bibliografia literatury polskiej „Nowy Korbut”, [t.] 5: Oświecenie. Hasta osobowe I-O, oprac. E. Aleksandrowska z zespołem, red. tomu do r. 1958 T. Mikulski, Warszawa 1967, s. 304.

9 E. Aleksandrowska, op. cit., s. 340. 
zadania rozwoju bibliotek naukowych, zorganizowanej w Kijowie 3-5 października $20 I 7$ roku przez Narodową Bibliotekę Ukrainy im. W.I. Wernadskiego w Kijowie, Narodową Akademię Nauk Ukrainy oraz Międzynarodową Asocjację Akademii Nauk $^{10}$. W nieco późniejszej rozprawie o berdyczowskim księgozbiorze klasztornym ${ }^{\mathrm{II}}$, opublikowanej także w roku 20I7, Ciborowska-Rymarowicz stwierdza:

》 Do tej pory ustaliłam, że ukazało się pięć edycji Polusi z rokiem I789 wytłoczonym na kartach tytułowych. Jedną edycję zidentyfikowano jako berdyczowską [...]. Egzemplarz Polusi ze zbioru Biblioteki Instytutu Badań Literackich (sygn. XVIII.r.653.adl) jest inny - taki sam egzemplarz znajduje się w Dziale Rzadkiej Książki Biblioteki Narodowej im. W. Stefanyka we Lwowie (sygn. C wydania są przechowywane w Bibliotece Narodowej Ukrainy im. W.I. Wernadskiego (sygn. In. 6330) oraz w Bibliotece Uniwersytetu Wileńskiego (sygn. IV.4497). Egzemplarz czwartej edycji utworu W.I. Marewicza posiada Biblioteka Zakładu Narodowego im. Ossolińskich (sygn. XVIII-II.994). Egzemplarz piątego wydania znajdziemy w bibliotece PAN i PAU w Krakowie (sygn. St. Dr. 3I9). Przedstawiona informacja poszerza wiedzę o repertuarze druków oficyny karmelitańskiej i uzupełnia luki w wiedzy o edycjach opery W.I. Marewicza ${ }^{\mathrm{I2}}$.

10 Zob. I. Циборовська-Римарович, Невідоме бібліографї бердичівське видання опери-драми B.I. Маревича „Роlиsia”: історико-книгознавчий та друкарський аналіз, in: Бібліотека. Наука. Комунікаціл. Стрратегічні завдання розвитку наукових бібліотек: матеріали Міжнар. наук. конф. (Київ, 3-5 жовт. 2017р.), Київ 2017, s. 180-183. Tekst tego referatu dostępny jest także online: http://conference.nbuv.gov. ua/report/view/id/1110 (stan z 2 marca 2019 r.).

11 Eadem, Polonika $w$ księgozbiorze klasztornym karmelitów bosych w Berdyczowie (na podstawie katalogu z 1781 r.). Zarys problemu, „Z Badań nad Książką i Księgozbiorami Historycznymi” 2017, tom specjalny: Polonika w zbiorach obcych, s. 229-237.

12 Ibidem, s. 236. Informacje te są dla mnie szczególnie ważne, ponieważ w ramach projektu naukowego Narodowego Centrum Nauki przygotowuję wydanie krytyczne twórczości Wincentego Marewicza - docelowo jego całego dorobku pisarskiego. W tym miejscu chciałabym podziękować Irynie Ciborowskiej-Rymarowicz za wszelkie informacje o sztuce Marewicza i pomoc w udostępnieniu mi online cyfrowej wersji (nieznanych mi wówczas) dwóch egzemplarzy Polusi... ze zbiorów Biblioteki Narodowej Ukrainy im. W.I. Wernadskiego w Kijowie. Z przykrością odnotowuję jednak fakt, iż w przywołanym wyżej artykule o polonikach w księgozbiorze klasztornym karmelitów bosych w Berdyczowie ukraińska badaczka nie zamieściła jakiejkolwiek informacji o tym, że wiadomości o niektórych egzemplarzach sztuki Marewicza (wraz z sygnaturami) pochodziły ode mnie. Na dwa egzemplarze Polusi... pochodzące ze zbiorów Biblioteki Instytutu Badań Literackich PAN w Warszawie oraz Biblioteki PAU i PAN w Krakowie natrafiłam w czasie swoich długoletnich kwerend bibliotecznych. Informacje o nich pozwoliły Irynie Ciborowskiej-Rymarowicz na sprostowanie, że sztukę Marewicza wydano w 1789 roku nie cztery (jak dotąd sądziła), a pięć razy. Wiadomości o wskazanych dwóch egzemplarzach Polusi... ukraińska badaczka uzyskała ode mnie we wrześniu 2017 r., w trakcie nieformalnej współpracy naukowej, polegającej na obustronnym przekazywaniu w korespondencji elektronicznej informacji m.in. na temat poczynionych przez nas ustaleń w sprawie znanych edycji tekstu opery. Wymiana objęła ponadto zdjęcia niektórych stron poszczególnych wydań sztuki Marewicza, w moim przypadku dotyczyło to również egzemplarza Polusi... ze zbiorów Biblioteki PAU i PAN w Krakowie, którego digitalizacja została sfinansowana ze środków realizowanego przeze mnie 
$\mathrm{Na}$ podstawie zgromadzonych źródeł z epoki warto poszerzyć stan badań nad wydawniczymi losami Polusi... Marewicza informacjami o zachowanych egzemplarzach edycji sztuki z I789 roku (w tym również nieodnotowanych przez Irynę Ciborowską-Rymarowicz). Dane na ten temat ujęte zostały w tabeli I. Wiadomości podane $\mathrm{w}$ referacie ukraińskiej badaczki dopełniłam ustaleniami poczynionymi przeze mnie w czasie przeprowadzonych kwerend bibliotecznych (wyjazdowych i korespondencyjnych), a także dzięki materiałom pozyskanym w formie zdigitalizowanej ${ }^{\mathrm{i}}$. Warto również dodać informacje o dwóch egzemplarzach wydania sztuki Z I79I roku (we Lwowie?), zlokalizowanych w krajowych książnicach naukowych: Bibliotece Jagiellońskiej w Krakowie (sygn. 26665 I) i Bibliotece Zakładu Narodowego im. Ossolińskich we Wrocławiu (sygn. XVIII-I2063).

\section{Tabela r. Egzemplarze edycji Polusi... z roku I789 $9^{\mathrm{I}}$}

\begin{tabular}{|c|c|}
\hline $\begin{array}{c}\text { Oznaczenie } \\
\text { wydania }\end{array}$ & Lokalizacja \\
\hline $\begin{array}{c}\text { A } \\
\text { ss. } 93\end{array}$ & $\begin{array}{l}\text { I. Biblioteka Narodowa Ukrainy im. W.I. Wernadskiego w Kijowie, sygn. Воц. комітет } \\
\text { I400; [Berdyczów]: [Drukarnia Karmelu Fortecy Najświętszej Marii Panny]. }\end{array}$ \\
\hline $\begin{array}{l}\text { B } \\
\text { ss. } 96\end{array}$ & $\begin{array}{l}\text { I. Biblioteka Narodowa Ukrainy im. W.I. Wernadskiego w Kijowie, sygn. Ін. } 6330 . \\
\text { 2. } \text { Biblioteka Wileńskiego Uniwersytetu, sygn. IV.4497. }\end{array}$ \\
\hline $\begin{array}{c}\mathrm{C} \\
\text { ss. } 93\end{array}$ & 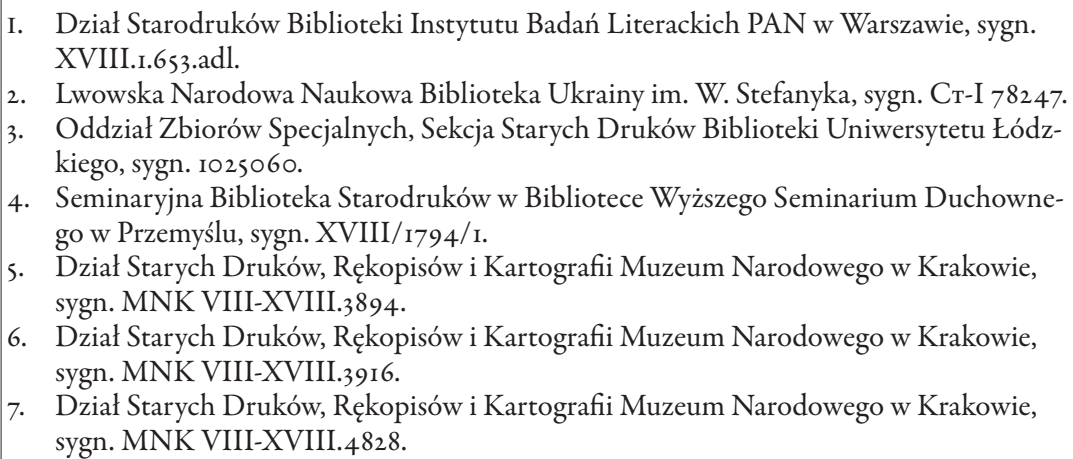 \\
\hline
\end{tabular}

projektu naukowego NCN. Wbrew deklaracjom i zapewnieniom, ukraińska badaczka nie podała w swojej publikacji, że ważne ustalenia naukowe w sprawie wydań tego dzieła poczyniła m.in. dzięki uzyskanym ode mnie informacjom i przesłanym materiałom.

13 W tym miejscu składam serdeczne podziękowania pracownikom bibliotek w kraju i za granicą (w szczególności Biblioteki Muzeum Narodowego w Warszawie, Działu Starych Druków, Rękopisów i Kartografii Muzeum Narodowego w Krakowie oraz Zakładu Starych Druków Biblioteki Narodowej w Warszawie) za życzliwość i pomoc okazaną mi podczas kwerend dotyczących opery Marewicza.

14 Wskazane w tabeli edycje Polusi... z 1789 r. nie zostały uporządkowane chronologicznie, nie udało się bowiem dotąd ustalić, w jakiej kolejności ukazywały się one w druku. 


\begin{tabular}{|c|c|}
\hline $\begin{array}{l}\text { D } \\
\text { ss. } 96\end{array}$ & $\begin{array}{l}\text { I. Dział Starych Druków Biblioteki Zakładu Narodowego im. Ossolińskich we Wrocła- } \\
\text { wie, sygn. XVIII-II.994. } \\
\text { 2. Biblioteka Muzeum Narodowego w Warszawie, sygn. SD } 5203 . \\
\text { 3. Dział Starych Druków, Rękopisów i Kartografii Muzeum Narodowego w Krakowie, } \\
\text { sygn. MNK VIII-XVIII.3915. }\end{array}$ \\
\hline $\begin{array}{c}\mathrm{E} \\
\text { ss. } \mathrm{IO}\end{array}$ & $\begin{array}{l}\text { I. Dział Zbiorów Specjalnych Biblioteki PAU i PAN w Krakowie, sygn. PAU St. Dr. } \\
\text { 2. Zakład Starych Druków Biblioteki Narodowej w Warszawie, sygn. XVIII.2.2515. }\end{array}$ \\
\hline
\end{tabular}

Wskazane edycje z I789 roku różnią się formatem, składem, liczbą stron, a także wyposażeniem typograficznym. Już połączona $\mathrm{z}$ kolacjonowaniem tekstu analiza porównawcza dwóch egzemplarzy: $\mathrm{C}_{\text {I }}$ i Eı pozwoliła ujawnić wiele odmian w tekstach (między innymi różnice w długości partii dialogowych, w szczegółowości opisów, doborze epitetów, rozległości porównań) oraz liczne inne warianty lekcji, a także błędy druku.

Należy dodać, że trzy egzemplarze wydań Polusi... z roku I789 znajdują się również w zbiorach Biblioteki Rosyjskiej Akademii Nauk w Petersburgu pod następującymi sygnaturami: XXIXб 27248; XXIXб 27431; XXIXб 28513. W opisach katalogowych odnotowano, że wszystkie trzy liczą po ıog stron, a zatem można przypuszczać, że pochodzą z wydania oznaczonego w tabeli jako E. Ponadto jeden egzemplarz Polusi... zachował się w zbiorach Rosyjskiej Biblioteki Narodowej w Petersburgu - sygn. 13.21.7.15. W opisie katalogowym brak informacji o autorze, podano tu jedynie format (80) i rok wydania (I789). Niewątpliwie konieczne jest dotarcie do tych egzemplarzy sztuki i porównanie ich z innymi, które mają taką samą datację roczną. Nie można bowiem wykluczyć, że pochodzą one z nieznanych dotąd wydań tego dzieła.

Długa lista egzemplarzy sztuki Marewicza pochodzących z różnych wydań i zachowanych w licznych bibliotekach krajowych oraz zagranicznych bez wątpienia świadczy o niezwykłej popularności tego dzieła na terenach Pierwszej Rzeczypospolitej. Równocześnie jednak sporządzony wykaz uświadamia, jak żmudna i trudna będzie praca nad edycją krytyczną tego utworu. Ale duża liczba zachowanych przekazów dzieła może się też okazać bardzo pomocna dla edytora w trakcie odczytywania kłopotliwych dla niego miejsc tekstu, wiadomo mi bowiem, że niektóre egzemplarze są uszkodzone, i to w różnym stopniu. Do zbadania pozostaje także kwestia finansowania wszystkich edycji Polusi... Dotąd nie udało się ustalić, czy to sam Marewicz, czy też inne osoby bądź instytucje wydawnicze łożyły na druk tej opery.

Świadectwem dużego zainteresowania operą Marewicza jest również znajdujący się w Bibliotece Zakładu Narodowego im. Ossolińskich we Wrocławiu manuskrypt ze sporządzonym przez nieznaną osobę odpisem przedmowy Do Czytelni$k a^{\mathrm{I5}}$ (w bloku notatek na tematy polityczne i historyczne, tzw. silva rerum), a także 
odpis całego tekstu $\mathrm{z}$ wydania opery w roku I79I, dostępny w zbiorach Biblioteki Jagiellońskiej w Krakowie ${ }^{\mathrm{I}}$. W tym miejscu warto też wspomnieć o włączeniu niektórych pieśni z tej opery do śpiewników z epoki. Między innymi w antologii zatytułowanej Rozrywka w smutku, czyli piosnki $i$ arie zebrane roku 1796 znalazły się Pieśn w tonie pocztarskim, Pieśn w tonach z ruska wesotych oraz Aria Polusia ${ }^{17}$. Ponadto Pieśn w tonach z ruska wesolych włączono do pierwszego tomu zbioru Śpiewy i arie teatralne i światowe z różnych oper i komedii zebrane z dodatkiem nowych śpiewów i krakowiaków z $\mathrm{I} 8 \mathrm{I} 6 \mathrm{roku}^{\mathrm{I}}$. Podczas kolacjonowania tekstów pieśni zamieszczonych $\mathrm{w}$ śpiewnikach $\mathrm{z}$ ich zapisem $\mathrm{w}$ jednym $\mathrm{z}$ wydań opery Marewicza stwierdziłam nieliczne odmiany i błędy drukarskie.

Opera Polusia... Wincentego Marewicza jest polityczno-okolicznościowym utworem o wymowie alegorycznej. Elżbieta Aleksandrowska nazywa tę sztukę „udramatyzowanym traktatem politycznym” ${ }^{\text {19 }}$, Ryszard Łużny określa ją jako „sceniczny pamflet wymierzony przeciwko polityce Rosji w stosunku do Polski”2o, Dobrochna Ratajczakowa uważa, że jest to „sceniczna alegoria zlokalizowana w miejscowości Wolność” nizowanym pamfletem antyrosyjskim"22.

Bohaterami sztuki są: Swobodzki - „dziedzic dóbr nazywających się Wolność, w opiece będący”; Przemocka - „mająca pod opieką Swobodzkiego”; Polusia „córka kołodzieja tej włości, służąca za pokojową u Przemockiej, ukochana potem od wiecznika ${ }^{23}$ swego Swobodzkiego”; Potężnicki - „przyjaciel Przemockiej”; Lito-

16 Biblioteka Jagiellońska w Krakowie, rkps 7116 I.; https://jbc.bj.uj.edu.pl/publication/410157/content ( $\operatorname{stan} \mathrm{z} 2$ marca 2019 r.).

17 Rozrywka w smutku, czyli piosnki i arie zebrane roku 1796, Warszawa [1796], s. 23-27; Biblioteka Jagiellońska w Krakowie, sygn. St. Dr. 5136 I.; http://jbc.bj.uj.edu.pl/dlibra/doccontent?id=86124 (stan z 2 marca 2019 r.).

18 Zob. Pieśń $w$ tonach $z$ ruska wesotych $\mathrm{w}$ tomie: Śpiewy $i$ arie teatralne $i$ światowe $z$ różnych oper $i$ komedii zebrane z dodatkiem nowych śpiewów i krakowiaków, nakładem J. Pukszty, Warszawa 1816, s. 187-188, egz. BN sygn. I 381.648.; https://polona.pl/item/spiewy-i-arye-teatralne-i-swiatowe-z-roznych-oper-i-komedyi-zebrane-z-dodatkiem-nowych,MTgxODQwOTc/ (stan z 2 marca 2019 r.).

19 E. Aleksandrowska, op. cit., s. 335.

20 R. Łużny, Bohomolec i Bogustawski w Rosji. ( $Z$ dziejów powiąań literackich polsko-rosyjskich doby Oświecenia), „Slavia Orientalis” 1961, nr 2, s. 147.

21 D. Ratajczakowa, Komedia oświeconych 1752-1795, Warszawa 1993, s. 331.

22 M. Piszczkowski, Zagadnienia wiejskie w literaturze polskiego Oświecenia, cz. 2, Wrocław 1963, s. 27.

23 Wiecznik - 'właściciel ziemi'; tu zarazem: wiecznik miłości - 'stale, wiecznie kochający'. 
śnicki - „sąsiad, pokrewny i przyjaciel Swobodzkiego”; Dokumentowicz - „prawnik służący u Przemockiej”; Ciemiężnicki - „poddany wspólny Przemockiej i Potężnickiego, natrętny lubownik Polusi” oraz dwaj sędziwi wieśniacy. Karol Estreicher rozszyfrował te alegoryczne postaci: „Polusia znaczy Polska, Swobodzki - Poniatowski, Przemocka - Katarzyna II, Potężnicki - Potiomkin, Ciemiężnicki - poseł rosyjski” ${ }^{24}$. Te informacje ujęte są w niezidentyfikowanych autorsko odręcznych zapisach w egzemplarzu Ei na karcie [3] verso, gdzie ponadto rozszyfrowano postać Litośnickiego jako „króla pruskiego”.

W swojej operze Marewicz za pomocą alegorii przedstawił konflikt polsko-rosyjski. Akcja sztuki rozgrywa się w posiadłości Wolność pod Nowogródkiem. Swobodzki (Stanisław August Poniatowski), którym „opiekuje się” Przemocka (Katarzyna II), pragnie ożenić się z ukochaną Polusią (Polską) - córką kołodzieja, która jest służącą Przemockiej. Jednak ta ostatnia wraz ze swoim przyjacielem Potężnickim (Potiomkin) nie chcą dopuścić do tego ślubu. Postanawiają wydać Polusię, wbrew jej woli, za ich wspólnego poddanego Ciemiężnickiego (poseł rosyjski) i z pomocą prawnika Dokumentowicza zamierzają podstępem przywłaszczyć sobie dziedzictwo Swobodzkiego. Planują przekupić mieszkańców Wolności oraz przeciągnąć na swoją stronę Litośnickiego (król pruski). Nie udaje się jednakże zrealizować tych podstępnych zamiarów, Litośnicki pomaga bowiem Polusi oraz Swobodzkiemu i młoda para szczęśliwie wiąże się ze sobą. Przemocka uwalnia Swobodzkiego spod swej „opieki” i przywraca mu jego dobra, a Polusię za jej wierną służbę nagradza wolnością. W ostatniej scenie opery pojawiają się dwaj wieśniacy i wyrażają radość z powodu powrotu Swobodzkiego do swoich włości oraz szczęścia państwa młodych. Jednocześnie skarżą mu się na brak miłosierdzia i sprawiedliwości, a także na ucisk panów, karczmarzy („chytrych Żydów”), posesorów, rządców i proszą go o pomoc. Swobodzki obiecuje, że ukróci wyzysk ze strony właścicieli gruntów i majątków, obdarzy chłopów wolnością „sprzedawania wszędzie i wszystkich produktów”, zlikwiduje „szkodliwe temu monopolia”, ponadto zadba o miasta („miastom porządek przepiszę i w nich, dozwalając swobody, postaram się, aby były ludne, i bogate”). Sztukę kończy śpiewana przez wieśniaków aria ,w tonach wiejskich"25.

We wszystkich znanych mi wydaniach Polusi... zamieszczone zostały trzy elementy tworzace jego literacką ramę wydawniczą ${ }^{26}$ : motto, list dedykacyjny

24 K. Estreicher, Bibliografia polska, cz. 3, t. 11 (22)..., s. 151.

25 Por. też M. Piszczkowski, op. cit., s. 27.

26 Zob. R. Ocieczek, O różnych aspektach badań literackiej ramy wydawniczej w ksiażkach dawnych, w: O literackiej ramie wydawniczej w ksiażkach dawnych, red. R. Ocieczek, Katowice 1990, s. 7-11; eadem, Rama utworu, w: Stownik literatury staropolskiej. Średniowiecze - renesans - barok, red. T. Michałowska, przy udziale E. Sarnowskiej-Temeriusz, B. Otwinowskiej, Wrocław 1990, s. 684-687. 
i przedmowa ${ }^{27}$. Na karcie tytułowej recto widnieje opatrzony skróconym podpisem cytat:

\section{1) Sławny tryumf, co zadziwia, Większy ten, co uszczęśliwia.}

\section{Krasic.}

Epigraf ten pochodzi z utworu Do... („Szczęście to jest dla narodu...”), który Ignacy Krasicki skierował do nierozpoznanego dotąd przez badaczy adresata. W zbiorze Listy z wierszami oświeceniowego poety tekst ten we współczesnych edycjach opatrzony jest numerem dwudziestym piątym ${ }^{28}$.

Bezpośrednio po karcie tytułowej widnieje list dedykacyjny, opatrzony następującą formułą inskrypcyjną: Jaśnie Wielmożnemu J[ego] M[oś]ci Panu Ogińskiemu, hetmanowi wielkiemu $W$ [ielkiego] $K s$ [ięstwa] $L$ [itewskiego], kawalerowi orderów wielu, Panu Dobrodziejowi ofiaruję. Nie wiadomo, czy jakieś bliższe więzi łączyły Marewicza z Michałem Kazimierzem Ogińskim i jakie szczególne powody zdecydowały o przypisaniu mu opery. Nie ulega jednak wątpliwości, że wybranie go na patrona dzieła to trafna decyzja. Ogiński był bowiem wirtuozem instrumentalistą, kompozytorem, librecistą, a założony i utrzymywany przez niego teatr w Słonimiu miał być swoistą świątynią sztuki operowej. Do tych kwestii odniósł się Andrzej Ciechanowiecki:

\L Literacką atmosferę Słonimia charakteryzuje również fakt, że W. Marewicz swój przekład z języka rosyjskiego na polski opery tragicznej w dwóch aktach Polusia, córka kotodzieja, czyli Wolnośc oswobodzona, o wyraźnym społecznym i narodowym nastawieniu, zadedykował hetmanowi ${ }^{29}$.

Ważną kwestią, która wymaga zbadania, są relacje między Wincentym Marewiczem i Michałem Kazimierzem Ogińskim. Należałoby ustalić, czy przypad-

27 Szerzej na ten temat zob. A. Petlak, Przyczynek do badań nad ramą wydawnicza utworów dramatycznych Wincentego Ignacego Marewicza, „Acta Universitatis Lodziensis. Folia Litteraria Polonica” 2016, 4 (34): Na szlakach literatury... Prace literaturoznawcze i edytorskie ofiarowane Profesor Barbarze Wolskiej z okazji siedemdziesiątych urodzin oraz czterdziestolecia pracy naukowej, s. 147-162.

28 Zob. ten utwór w edycji: I. Krasicki, Dzieta zebrane, pod red. Z. Golińskiego, kontynuowaną przez J.T. Pokrzywniaka i M. Parkitnego, t. 2: Zbiory wierszy, oprac. T. Kostkiewiczowa, red. nauk. A.P. Lesiakowski, Poznań 2019, s. 298.

29 А. Цеханавецкі, Міхал Казімір Агінскі і яго „Сядзіба музау” у Слоніме, Мінск 1993, s. 72; jeśli nie zaznaczono inaczej, przekłady pochodzą od autorki artykułu. W polskiej wersji przytoczonej wypowiedzi skorygowany został błędny zapis w ukraińskim oryginale inicjału imienia oraz nazwiska pisarza: „J. Marcewicz”. Ciechanowiecki błędnie sądzi, iż Polusia... jest przekładem z języka rosyjskiego. Przy czym należy dodać, że do tej opinii przyczynił się sam autor, o czym będzie mowa w dalszym wywodzie. 
kiem Polusia... nie była sztuką przygotowaną specjalnie dla teatru słonimskiego. To przypuszczenie nie jest bezpodstawne, zważywszy, że wśród utworów autorstwa samego Ogińskiego są sztuki o podobnym charakterze. Nie można też wykluczyć, że to właśnie ten kompozytor napisał muzykę do Polusi... Być może Marewicz zadedykował operę hetmanowi z myślą o wystawieniu jej w teatrze słonimskim bądź na innej scenie pozostającej pod opieką Ogińskiego. Należy przy tym dodać, że sztuka Marewicza była bez wątpienia utworem przeznaczonym do wystawienia $\mathrm{w}$ teatrze muzycznym. Potwierdza to zarówno wskazany w podtytule gatunek „opera tragiczna”, jak i heterorytmiczny charakter tekstu. Są tu partie z wyraźnym podziałem na zwrotki i refreny, a ponadto wskazówki typu „Pieśń w tonie pocztarskim $z$ trąbką po każdej strofie, akomodując trzaskaniem z bicza”, które upewniają, że dany fragment tekstu ma charakter słowno-muzyczny ${ }^{30}$. Dodajmy, że operę Marewicza wystawiono w roku $1795 \mathrm{w}$ Wilnie ${ }^{3 \mathrm{I}}$.

Trzecie preliminarium, w edycjach sztuki zamieszczone po dedykacji, to przedmowa skierowana Do Czytelnika ${ }^{32}$. Pisarz informuje w niej, dlaczego na karcie tytułowej i na końcu wypowiedzi wstępnej („A teraz przedmowę kończę słowami autora Monachomachii: «Czytaj i dozwól, niech czytają twoi»"33) odwołał się do utworów Krasickiego i podał autorstwo biskupa warmińskiego. Dzieli się ponadto z czytelnikiem informacjami o problemach i trudnościach, jakie towarzyszyły mu przy tłumaczeniu sztuki.

Jak się jednak okazuje, zarówno zawarta w przedmowie wypowiedź pisarza o problemach, z którymi jakoby zmagał się w trakcie dokonywania przekładu opery z języka rosyjskiego, jak i dodana do tytułu informacja, że sztuka została „z rosyjskiego na polski język przetłumaczona”, były mistyfikacjami mającymi na celu zamaskowanie rzeczywistej treści i ostrej wymowy politycznej dzieła. W przypadku Polusi... mamy do czynienia z sytuacją odwrotną, ponieważ pod koniec XVIII wieku polski utwór został przełożony na język rosyjski przez Wasilija Anastasiewicza (1775-1845) - rosyjskiego bibliografa i tłumacza, popularyzatora kultury polskiej w Rosji. Przekładem tym jako pierwszy zainteresował się wspomniany już

30 Składam podziękowania dr Lidii Ignaczak za wszelkie wskazówki pomocne w badaniach dotyczących relacji między Marewiczem a Ogińskim.

31 Encyklopedia Ziemi Wileńskiej, t. 2, Literatura Ziemi Wileńskiej od XVI wieku do 1945 roku, Bydgoszcz 2004, cyt. za: S. Hałabuda, J. Michalik, A. Stafiej, przy współpracy B. Maresz, A. Przybyszewskiej, Dramat polski 1765-2005. Przedstawienia, druki, archiwalia, t. 2: M-Ż, Warszawa 2014, s. 571.

32 W wydaniach A, B, C, D przedmowę zamieszczono na jednej, a w wydaniu E - na dwóch stronicach. Na temat wypowiedzi wstępnej Marewicza Karol Estreicher zamieścił następującą adnotację: „Przy jednym egzemplarzu widziałem obszerną samochwalczą przedmowę, ale tej w innych znanych nie ma. Przedmowa ta godna byłaby przedruku, tak jest jowialna” (Bibliografia polska, cz. 3, t. 11 (22)..., s. 151). O tekście tym wspomina również Paweł Naumowicz Bierkow (zob. idem, Pусско-польские литературные связи в XVIII веке, Москва 1958, с. 43).

33 I. Krasicki, Dzieta zebrane, t. 1: Poematy, oprac. Z. Goliński, Wrocław-Warszawa-Kraków 1998, s. 165. 
rosyjski literaturoznawca, badacz rosyjsko-polskich stosunków literackich Paweł Bierkow $^{34}$. W końcowej części swej wypowiedzi poświęconej rosyjskiemu tłumaczeniu libretta opery Bierkow stwierdza: „Możliwe, że jako dokument polityczny Polusia zwróciła uwagę Anastasiewicza, który tłumaczył ją od I794 do I796 r., ale wydrukować, oczywiście, swojego tłumaczenia nie mógł”35.

Przekład rosyjski faktycznie nigdy nie ukazał się drukiem, a jego rękopis znajduje się obecnie w zbiorach Rosyjskiej Biblioteki Narodowej w Petersburgu ${ }^{36}$.

W sprawozdaniu Cesarskiej Biblioteki Publicznej w Piotrogrodzie za rok I9I2 na liście zakupionych rękopisów pod numerem piętnastym znajduje się następująca adnotacja:

\section{》 Полюся, дочь колесника, или Освобожденная вольность. Опера трагическая въ двухъ АБйствіяхъ. Переводъ съ польскаго. В. Анастасьвичемъ. \\ Славный есть тріумфъ тотъ, что удивляетъ, Но тотъ славнђе, что осчастиивмяетъ. I794 года. Въ сель Успенскомъ ${ }^{37}$.}

Podano również sygnaturę tego manuskryptu (O.XV.2o) oraz informację, że jest to thumaczenie wydanego w roku I789 lub I79I utworu pt. Polusia, córka kotodzieja, czyli Wolnośc oswobodzona. Opera tragiczna w dwóch aktach, z rosyjskiego na polski język przetłumaczona. Osoba, która opracowała sprawozdanie, za bibliografią Karola Estreichera wskazała autora opery - Wincentego Marewicza, dodając, że jego sztuka jest utworem oryginalnym, a nie tłumaczeniem.

34 П.Н. Берков, op. cit., с. 43-45. O tym tłumaczeniu (powołując się na pracę Bierkowa) wspomina Siergiej Nikołajew (Adam Naruszewicz i Franciszek Karpinski w „Cudzej muzie” Wasilija G. Anastasiewicza, w: idem, Od Kochanowskiego do Mickiewicza. Szkice z historii polsko-rosyjskich związków literackich XVII-XIX wieku, tłum. J. Głażewski, Warszawa 2007, s. 242; idem, Polsko-rosyjskie związi literackie w epoce Stanistawa Augusta Poniatowskiego, „Ruch Literacki” 2003, z. 1, s. 2). Zob. także A.W. Lipatow, op. cit., s. $158,177$.

35 П.Н. Берков, op. cit., с. 45.

36 В. Анастасевич, Полюся дочь колесника или Освобожденная вольность. Опера трагическая в двух действиях. Перевод с польского, Rosyjska Biblioteka Narodowa w Petersburgu, rkps O.XV.20.

37 Отчеть Императорской Публиной Библіотеки за 1912 годъ, Петроградъ 1917, с. 109-110; http:// gpntb.dlibrary.org/ru/nodes/3516-otchet-imperatorskoy-publichnoy-biblioteki-1912-g-b-m-1917 (stan z 2 marca 2019 r.).

Thumaczenie przytoczonej adnotacji:

'Polusia, córka kołodzieja, czyli Oswobodzona wolność. Opera tragiczna w dwóch aktach. Tłumaczenie z polskiego W. Anastasiewicza.

Sławny triumf, co zadziwia,

Większy ten, co uszczęśliwia.

1794 roku. We wsi Uspienskoje.' 
Zachowany w dobrym stanie rękopis ma niewielki format - I/8 arkusza (octavo), twardą oprawę; obejmuje pięćdziesiąt siedem stron. Co ważne, na karcie tytułowej tłumaczenia znajduje się informacja (powtórzona w sprawozdaniu): „1794 года. Въ сель Успенскомъ” - 'I794 roku. We wsi Uspienskoje', a na ostatniej stronie odnotowano: „Окончимъ переводъ съ польскаго 1796-го, марта 17-го дня, въ сель Земънкахъ (Богославской округи владьнія Ржевуцкаго)” - 'Zakończył tłumaczenie z polskiego I796-go, marca I7-ego dnia, we wsi Zielonki (Bogosławskiego okręgu posiadłości Rzewuckiego [Rzewuskiego - A. P.])'. Ta niezwykle istotna informacja jeszcze raz potwierdza, że polski tekst Polusi... nie jest przekładem z języka rosyjskiego, lecz utworem oryginalnym.

$\mathrm{Z}$ przeprowadzonej przeze mnie wstępnej analizy porównawczej tekstu Marewicza $\mathrm{z}$ rosyjskim tłumaczeniem wynika, że mamy do czynienia z przekładem całego dzieła w dwóch aktach. Pominięte zostały jedynie dwa preliminaria: dedykacja dla Michała Kazimierza Ogińskiego i przedmowa Do Czytelnika, co jest w pełni zrozumiałe. Przekład miał funkcjonować w nowym kontekście, stąd poświęcenie utworu hetmanowi straciło sens, a ponadto w nowych okolicznościach zupełnie nieistotne stały się mistyfikacyjne zabiegi Marewicza, piszącego o problemach, z którymi jakoby się zmagał, tłumacząc operę. Dodajmy, że translacja rosyjska jest wiernym przekładem. Liczne przekreślenia w tekście, odnotowane na marginesach synonimy użytych słów, nie zawsze dokładny pod względem rymu i miary wersyfikacyjnej przekład partii wierszowanych świadczą o tym, że jest to wersja robocza.

Na obecnym etapie moich badań trudno jednoznacznie stwierdzić, z którego polskiego wydania dzieła korzystał tłumacz rosyjski. Wiadomo, że w zbiorach Rosyjskiej Biblioteki Narodowej w Petersburgu znajduje się jeden egzemplarz Polusi... Marewicza z I789 roku (sygn. 13.21.7.I5). W opisie katalogowym brak jednak informacji o liczbie stron. $Z$ kolei we wspomnianym sprawozdaniu za rok I9I2 podano, że jedyny egzemplarz polskiego dzieła w piotrogrodzkiej książnicy pochodzi z i789 roku i liczy Io9 stron. Być może o nim właśnie wspominał Paweł Naumowicz Bierkow. Taką samą objętość ma wydanie, z którego dwa egzemplarze, krakowski i warszawski, odnotowane są w tabeli jako Eı i E2. Jednak już porównanie tekstu początkowych stron aktu I Polusi... w tych egzemplarzach $\mathrm{z}$ rękopisem Wasilija Anastasiewicza skłania do przypuszczeń, że tłumacz rosyjski posiłkował się innym wydaniem sztuki Marewicza. Tabela 2 zawiera kilka fragmentów polskiego dzieła w edycjach z lat I789 (oznaczonych jako E, A, C) i wydania z I79ı roku oraz w przekładzie rosyjskiego bibliografa. 
Tabela 2. Fragmenty Polusi... z edycji I789, I79I i z rosyjskiego przekładu

\begin{tabular}{|c|c|c|c|c|}
\hline \multicolumn{2}{|c|}{$\begin{array}{l}\text { Polusia... } \\
\text { I789-E }\end{array}$} & \multicolumn{2}{|c|}{$\begin{array}{c}\text { Polusia... } \\
\text { I789- A, C; I79I }\end{array}$} & \multirow{2}{*}{$\begin{array}{c}\text { Polusia... } \\
\text { Przekład Wasilija } \\
\text { Anastasiewicza }\end{array}$} \\
\hline Lokalizacja & Tekst & Lokalizacja & Tekst & \\
\hline $\begin{array}{c}\text { S. I } \\
\text { Didaskalia }\end{array}$ & $\begin{array}{l}\text { Włosy rozczo- } \\
\text { chrane widać mu } \\
\text { spod szlafmycy. }\end{array}$ & $\begin{array}{c}\text { s. I } \\
\text { Didaskalia }\end{array}$ & $\begin{array}{l}\text { Włosy widać mu } \\
\text { spod szlafmycy. }\end{array}$ & $\begin{array}{l}\text { Из под колпака } \\
\text { видны у него } \\
\text { волосы. } \\
\quad \text { k. } 2 \text { recto }\end{array}$ \\
\hline $\begin{array}{c}\text { s. I } \\
\text { SWOBODZKI }\end{array}$ & $\begin{array}{l}\text { nie zważając, czy } \\
\text { dół, czy góra, czy } \\
\text { kamień. }\end{array}$ & $\begin{array}{c}\text { s. } 2 \\
\text { SWOBODZKI }\end{array}$ & $\begin{array}{l}\text { nie zważając, czy } \\
\text { góra, czy kamień. }\end{array}$ & $\begin{array}{l}\text { не смотря ни гор, } \\
\text { ни камней. } \\
\text { k. } 2 \text { verso }\end{array}$ \\
\hline $\begin{array}{c}\text { s. } 3 \\
\text { SWOBODZKI }\end{array}$ & $\begin{array}{l}\text { lecieć tu jak } \\
\text { szalony mil } \\
\text { kilkadziesiąt }\end{array}$ & $\begin{array}{c}\text { edycja A i C: } \\
\text { s. } 2 \\
\text { SWOBODZKI; } \\
\text { edycja I79I: } \\
\text { s. } 3 \\
\text { SWOBODZKI }\end{array}$ & $\begin{array}{l}\text { lecieć tu mil kilka- } \\
\text { dziesiąt }\end{array}$ & $\begin{array}{c}\text { и мететь несколько } \\
\text { десятков мимь } \\
\text { k. } 3 \text { verso }\end{array}$ \\
\hline $\begin{array}{c}\text { s. } 3 . \\
\text { SWOBODZKI }\end{array}$ & $\begin{array}{l}\text { co delikatne } \\
\text { ciało oddać } \\
\text { dobrowolnie na } \\
\text { okrutne męki }\end{array}$ & $\begin{array}{c}\text { s. } 3 . \\
\text { SWOBODZKI }\end{array}$ & $\begin{array}{l}\text { się oddać dobrowol- } \\
\text { nie na okrutne męki }\end{array}$ & $\begin{array}{l}\text { произвольно } \\
\text { отдаться } \\
\text { жесточайшим } \\
\text { мучениям } \\
\text { k. } 3 \text { verso }\end{array}$ \\
\hline $\begin{array}{c}\text { s. 3-8 } \\
\text { SWOBODZKI }\end{array}$ & $\begin{array}{l}\text { [Kontynuacja } \\
\text { wypowiedzi } \\
\text { Swobodzkiego] }\end{array}$ & - & $\begin{array}{l}\text { [Brak dalszej części } \\
\text { wypowiedzi] }\end{array}$ & $\begin{array}{l}\text { [Brak dalszej części } \\
\text { wypowiedzi] }\end{array}$ \\
\hline $\begin{array}{c}\text { s. } 9 \\
\text { POLUSIA }\end{array}$ & $\begin{array}{l}\text { ale owszem ja się } \\
\text { zadziwiam, że } \\
\text { WPana w tak } \\
\text { dobrej cerze } \\
\text { oglądam, musisz } \\
\text { cale nie mieć } \\
\text { czułości serca, } \\
\text { że go otaczające } \\
\text { okoliczności } \\
\text { bynajmniej nie } \\
\text { zastanawiają. }\end{array}$ & $\begin{array}{l}\text { s. } 3 \\
\text { POLUSIA }\end{array}$ & $\begin{array}{l}\text { ale owszem ja się } \\
\text { zadziwiam, że WPa- } \\
\text { na w dobrej cerze } \\
\text { oglądam. }\end{array}$ & $\begin{array}{l}\text { но так чудно, } \\
\text { что я вас вижу } \\
\text { в добром здоровье. } \\
\text { k. } 4 \text { recto }\end{array}$ \\
\hline
\end{tabular}

Jak widzimy, zapis tekstu sztuki Marewicza w pochodzących z I789 roku wydaniach A i C w przywołanych fragmentach różni się od jego lekcji w edycjach B, D i E. Można zatem przypuszczać, że przy tłumaczeniu opery Wasilij Anastasiewicz korzystał z egzemplarza dzieła $\mathrm{A}$ lub $\mathrm{C}$ bądź też za podstawę przekładu przyjął edycję z i79r roku. 
Oprócz Polusi, córki kotodzieja... Wincenty Ignacy Marewicz napisał jeszcze pięć innych utworów dramatycznych, a mianowicie trzy komedie: Mitość dla cnoty. Komedia oryginalna w trzech aktach (Warszawa I787), Mitośc wszystkich porównywa. Komedia oryginalna w pięciu aktach (b.m., I788; Wilno I796), Wszystko się skończyto na projekcie. Komedia oryginalna we dwóch aktach (b.m.r.) oraz dwie sztuki określone jako dramy: Szczęście w nieszczęściu, czyli Wzór statości ludzkości i cierpliwości. Drama oryginalne w czterech aktach (b.m., I798) i Żona opuszczona na bezludnej wyspie. Drama w jednym akcie, zintrygi wziętej z opery wtoskiej (Wilno 1795). Żaden z tych utworów nie spotkał się z takim zainteresowaniem jak Polusia... Spośród jego dzieł scenicznych właśnie ta opera zyskała największą popularność na terenach Pierwszej Rzeczypospolitej i zainteresowała także rosyjskiego tłumacza-bibliografa Wasilija Anastasiewicza. Do takiego powodzenia sztuki z pewnością przyczynił się polityczny charakter i - w rezultacie - patriotyczna wymowa dzieła, co podkreśliła Dobrochna Ratajczakowa w książce poświęconej komediom oświeceniowych twórców: „Opera zaszyfrowuje szansę kraju na niepodległość w sojuszu z Prusami $[\ldots]$ i wysuwa konkretny program politycznych reform" ${ }^{38}$.

Podsumowując zawarte w artykule rozważania, należy podkreślić, że na popularność omawianego utworu Wincentego Ignacego Marewicza złożyły się następujące czynniki: aktualność polityczna, a w tym zaakcentowanie programu reform stronnictwa patriotycznego, krytyka Rosji, wymowa propruska, a ponadto wyrazista alegoryczność opery i pamfletowy charakter tekstu. Przejawy tej popularności to siedem wydań opery w ciągu trzech lat, liczne egzemplarze zachowane w wielu bibliotekach w kraju i za granicą, odpis przedmowy do utworu i odpis całego tekstu dramatu z edycji z i79I roku, włączenie pieśni pochodzących z utworu do ówczesnych śpiewników, wystawienie sztuki na scenie wileńskiej w 1795 roku, a wreszcie dokonany pod koniec XVIII wieku przez Wasilija Anastasiewicza przekład tekstu na język rosyjski.

\section{BibLIOGRAFIA:}

\section{LITERATURA PODMIOTOWA:}

Anastasiewicz W. , Polusia docz' koliesnika ili oswobożdionnaja wolnost'. Opiera tragiczeskaja w dwóch diejstwijach. Pieriewod s polskogo, Rosyjska Biblioteka Narodowa w Petersburgu, rkps O.XV.20;

Marewicz W.I.], Polusia, córka kotodzieja, czyli Wolność oswobodzona. Opera tragiczna w dwóch aktach, z rosyjskiego na polski język przetłumaczona, [b.m.] 1789;

38 D. Ratajczakowa, op. cit., s. 331. To notabene tłumaczy przypisywanie autorstwa omawianej opery Niemcewiczowi. 
Polusia, córka kotodzieja, czyli Wolność oswobodzona. Opera tragiczna w dwóch aktach, z rosyjskiego na polski język przetłumaczona, [b.m.] 1791.

\section{LITERATURA PRZEDMIOTOWA:}

Aleksandrowska E., Wincenty Ignacy Marewicz (1755-1822), w: Pisarze polskiego oświecenia, red. T. Kostkiewiczowa, Z. Goliński, t. 2, Warszawa 1994, s. 332-349;

Bibliografia literatury polskiej „Nowy Korbut”, [t.] 5: Oświecenie. Hasta osobowe I-O, oprac. E. Aleksandrowska z zespołem, red. tomu do r. 1958 T. Mikulski, Warszawa 1967;

Bierkow P.N., Russko-polskije litieraturnyje swiazi w XVIII wiekie, Moskwa 1958;

Ciborowska-Rymarowicz I., Niewidome bibliobrafiji berdycziws'ke wydannia opery-dramy W.I. Marewycza «Polusia»: istoryko-knyhoznawczyj ta drukars'kyj analiz, w: Biblioteka. Nauka. Komunikacija. Stratehiczni zawdannia rozwytku naukowych bibliotek: materiaty Miżnar. nauk. konf. (Kijiw, 3-5 żowt. 2017 r.), Kijów 2017, s. 180-183, http://conference.nbuv.gov.ua/report/view/id/1110;

Ciechanowiecki A., Michat Kazimir Aginski i jaho „Siadziba muzau” u Stonimie, Mińsk 1993;

Estreicher K., Bibliografia polska XIX stulecia, t. 4: D-Dramat polski, wyd. 2, red. K. Estreicher (junior), Kraków 1966;

Bibliografia polska, cz. 2: Stulecie XV-XIX. Spis chronologiczny, t. 2 (9): Stulecie XVIII i dopetnienia do wieku XV-XVII, Kraków 1888;

Bibliografia polska, cz. 3, t. 11 (22): M-My, Kraków 1908;

Gomulicki J.W., Cośnowego o „Sprzeczkach” Jakuba Jasińskiego, w: W'sód pisarzy oświecenia. Studia i portrety, red. A. Czyż i S. Szczęsny, Bydgoszcz 1997, s. 171-203;

Hałabuda S., Michalik J., Stafiej A., przy współpracy B. Maresz, A. Przybyszewskiej, Dramat polski 1765-2005. Przedstawienia, druki, archiwalia, t. 2: $M-\dot{Z}$, Warszawa 2014;

Jackl J., Litteraria, w: Teatr Narodowy 1765-1794, red. J. Kott, oprac. J. Jackl, B. Król-Kaczorowska, J. Pawłowiczowa, K. Wierzbicka-Michalska, Z. Wołoszyńska, W. Zawadzki, Warszawa 1967, s. 425-426;

Krasicki I., Dzieta zebrane, pod red. Z. Golińskiego, kontynuowane przez J.T. Pokrzywniaka i M. Parkitnego, t. 2: Zbiory wierszy, oprac. T. Kostkiewiczowa, red. nauk. A.P. Lesiakowski, Poznań 2019;

Dzieta zebrane, t. 1: Poematy, oprac. Z. Goliński, Wrocław-Warszawa-Kraków 1998;

Lipatow A.W., Początki polskiej prozy preromantycznej XVIII wieku. Ewolucja myśli artystycznej oraz przemiany gatunkowe na tle narodowego i europejskiego procesu literackiego, tłum. J. Aulak i M. Dobrogoszcz, w: idem, Stowiańszczyzna - Polska - Rosja. Studia o literaturze i kulturze, Izabelin 1999, s. 147-178;

Łużny R., Bohomolec i Bogustawski w Rosji. ( $Z$ dziejów powiązań literackich polsko-rosyjskich doby Oświecenia), „Slavia Orientalis” 1961, nr 2, s. 145-166;

[Marewicz W.I.] Do Czytelnika, [odpis przedmowy], Zakład Narodowy im. Ossolińskich we Wrocławiu, rkps Ossol. 1198/I;

[Marewicz W.I.] Polusia, [odpis tekstu opery], Biblioteka Jagiellońska w Krakowie, rkps 7116 I., https://jbc. bj.uj.edu.pl/publication/410157/content;

Nikołajew S., Adam Naruszewicz i Franciszek Karpiński w „Cudzej muzie” Wasilija G. Anastasiewicza, w: idem, Od Kochanowskiego do Mickiewicza. Szkice z historii polsko-rosyjskich związków literackich XVII-XIX wieku, tłum. J. Głażewski, Warszawa 2007, s. 240-253;

Polsko-rosyjskie zwiąki literackie w epoce Stanistawa Augusta Poniatowskiego, „Ruch Literacki” 2003, z. 1, s. 1-8;

Ocieczek R., O różnych aspektach badań literackiej ramy wydawniczej w ksiażkach dawnych, w: O literackiej ramie wydawniczej w ksiażkach dawnych, red. R. Ocieczek, Katowice 1990, s. 7-19; 
Rama utworu, w: Stownik literatury staropolskiej. Średniowiecze - renesans - barok, red. T. Michałowska, przy udziale E. Sarnowskiej-Temeriusz, B. Otwinowskiej, Wrocław 1990, s. 684-688;

Otczet' Impieratorskoj Publicznoj Bibliotieki za 1912 god, Pietrograd 1917, s. 109-110, http://gpntb.dlibrary.org/ $\mathrm{ru} /$ nodes/3516-otchet-imperatorskoy-publichnoy-biblioteki-1912-g-b-m-1917;

Petlak A., Przyczynek do badań nad ramą wydawniczą utworów dramatycznych Wincentego Ignacego Marewicza, „Acta Universitatis Lodziensis. Folia Litteraria Polonica” 2016, 4 (34): Na szlakach literatury... Prace literaturoznawcze i edytorskie ofiarowane Profesor Barbarze Wolskiej z okazji siedemdziesiatych urodzin oraz czterdziestolecia pracy naukowej, s. 147-162;

Piszczkowski M., Zagadnienia wiejskie w literaturze polskiego Oświecenia, cz. 2, Wrocław 1963;

Ratajczakowa D., Komedia oświeconych 1752-1795, Warszawa 1993;

Rozrywka w smutku, czyli piosnki i arie zebrane roku 1796, Warszawa [1796], http://jbc.bj.uj.edu.pl/dlibra/doccontent ?id=86124;

Spis darów, uczynionych dla Zaktadu Narodowego imienia Ossolińskich oraz i dawców tychże, w ciagu roku 1833, „Czasopismo Naukowe od Zakładu Narodowego imienia Ossolińskich wydawane” 1833, z. 8, http://www.wbc. poznan.pl/dlibra/doccontent?id=114149;

Śpiewy i arie teatralne i światowe z różnych oper i komedii zebrane z dodatkiem nowych śpiewów i krakowiaków, nakładem J. Pukszty, Warszawa 1816, https://polona.pl/item/spiewy-i-arye-teatralne-i-swiatowe-z-roznych-oper-i-komedyi-zebrane-z-dodatkiem-nowych,MTgxODQwOTc/.

SŁowa KLucze: oświecenie, Wincenty Ignacy Marewicz, opera alegoryczna, Wasilij Anastasiewicz, przekład

\section{Анна ПетАяк}

\section{ИСТОРИЧЕСКИЕ ИСТОЧНИКИ КАК СВИАЕТЕАЬСТВА ПОАЬСКОЙ И РУССКОЙ РЕЦЕПЦИИ ОПЕРЫ ВИНЦЕНТИЯ ИГНАЦИЯ МАРЕВИЧА ПОЯЮСЯ, АОЧЬ КОАЕСНИКА, ИАИ ОСВОБОЖАЕННАЯ ВОАЬНОСТЬ...}

Предметом анализа в статье является приписываемая в свое время Юлиану Урсыну Немцевичу «трагическая опера» Винцентия Игнация Маревича Полюся, дочь колесника, или Освобожденная вольность... Эта пьеса напоминает амлегорическую Араму политического характера, где за персонажами скрываются реальные фигуры, такие как: Свободский (Станислав Август Понятовский), Пшемоцкая (Екатерина II), Потенжницкий (Потемкин), Цеменжницкий (русский посом), Аитосницкий (прусский король) и, наконец, заглавная Полюся как амлегория Польши.

Арама была опубликована анонимно во время Четырехлетнего сейма (в 1789 и І791 г. без указания места издания). Из-за ее антирусского характера она была подана как перевод с русского. Пьеса вызвала огромный интерес, о чем свидетельствуют, в т.ч., большое количество экземпляров, переписанный от руки текст целиком и рукопись преАисловия к произвеАению. Кроме того, в 1794-1796 гг. оперу перевел 
на русский язык Василий Анастасевич - библиограф, переводчик, издатель журнала «УАей», популяризатор польской Аитературы в России (автограф этого перевода находится в настоящее время в Национальной библиотеке в Петербурге).

КАЮчевЫЕ САОВА: просвещение, Винцентий Игнаций Маревич, алмегорическая опера, Васимий Анастасевич, перевоА

\section{Anna Petlak}

\section{Sources of the time as testament to Polish and Russian reception of} Wincenty Ignacy Marewicz's opera Polusla, córka kOzODZieja, CZyli

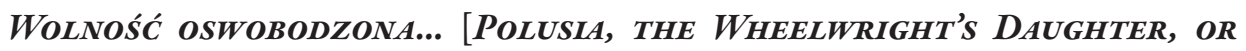
LIBERTY FREED...]

The article's subject of discussion is the 'tragic opera' by Wincenty Ignacy Marewicz, Polusia, córka kotodzieja, czyli Wolnosic oswobodzona... [Polusia, the Wheelwright's Daughter, or Liberty Freed... ], attributed at one point to Julian Ursyn Niemcewicz. The play resembles an allegorical tragedy of political nature, in which the characters conceal real-life figures, such as: Swobodzki (Stanisław August Poniatowski), Przemocka (Catherine the Great), Potężnicki (Potemkin), Ciemiężnicki (Russian envoy), Litośnicki (Prussian king), and finally, the eponymous Polusia, as an allegory of Poland.

The tragedy was printed anonymously during the Four-Year Sejm (I789 and I79I, without a place of publication). Due to its anti-Russian character, it was published as a translation from the Russian language. The play was met with immense interest, which can be demonstrated by, among other things, the numerous prints, a handwritten copy of the entire text, as well as a manuscript of the preface to the work. Moreover, in the years I794 to I796, the opera was translated into Russian by Vasily Anastasevich - a bibliographer, translator, publisher of the "УАей" magazine, and promoter of Polish literature in Russia (a draft version of the translation is currently stored in the National Library of Russia in Saint Petersburg).

KEYwords: the Enlightenment, Wincenty Ignacy Marewicz, allegorical opera, Vasily Anastasevich, translation 